\title{
Constelações ubíquas: Rumo a uma antropologia não antropocêntrica
}

\section{Ubiquitous constellations: Towards a non-anthropocentric anthropology}

\author{
MASSIMO CA NEVAC C I a \\ Università degli Studi di Roma "La Sapienza", Faculdade de Ciências da Comunicação. Roma - Itália
}

\section{RESUMO}

A divisão do conhecimento em disciplinas-disciplinadas, tal como foi estabelecida pela divisão do trabalho da era industrial, dividida em faculdades, departamentos, currículos etc., se dissolve no ar de pixels. A constelação conceitual do ensaio é baseada na indisciplina metodológica. A pesquisa no campo material e imaterial, analógico e digital mistura conceitos-chave: sincretismos culturais, polifonias narrativas, subjetividade ubíqua, diásporas inquietas, meta-fetichismos. O etnógrafo se move deslocado, atento aos menores detalhes nas paisagens que fluem; assim, aprende a se observar durante a pesquisa. No processo do método reflexivo, o pesquisador se descobre parte da pesquisa e a inconsistência dialética sujeito/objeto.

Palavras-chave: Indisciplina, ubiquidade, diásporas, polifonias, sincretismos, fetiches

\begin{abstract}
The division of knowledge into disciplined-disciplines, as established by the division of labor in the industrial age, divided into faculties, departments, curricula, etc., dissolves in the air of pixels. The conceptual constellation studied is based on methodological indiscipline. Research in the material and immaterial, analog and digital fields mixes key concepts: cultural syncretisms, narrative polyphonies, ubiquitous subjectivity, restless diasporas, meta-fetishisms. The ethnographer moves around, attentive to the smallest details in the flowing landscapes; thus, learning to observe itself during the research. In the process of the reflective method, the researcher discovers part of the research and the subject/object dialectical inconsistency.
\end{abstract}

Keywords: Indiscipline, ubiquity, diasporas, polyphonies, syncretisms, fetishes

${ }^{a}$ Doutor em Filosofia, professor de Antropologia Cultural na Faculdade de Ciência da Comunicação da Università degli Studi di Roma "La Sapienza”. Orcid: https://orcid. org/0000-0002-8269-0564. E-mail: maxx.canevacci@ gmail.com 


\section{INDISCIPLINA}

Pela primeira vez, os medicamentos e os tratamentos foram ineficazes em uma pneumonia aparentemente banal. Meu dever era curar aquele doente. Por exclusão, concluí que, se o conhecido falhasse, só me restava adentrar no desconhecido.

O coronavírus estava escondido bem ali. (Malara, 2020, para. 3)

${ }^{1}$ As referências a essa premissa devem cruzar o Perturbador com o Fracassado. Encontrar as relações desconhecidas entre Freud $(1977,1981)$ e Bernhard (1985) poderia constituir uma mistura adequada para os dias de hoje.

${ }^{2}$ Alusão ao termo "colpo d'occhio", isto é, a maneira espontânea do pesquisador, treinado na cultura visual, captar, entender rapidamente, em um átimo, um código, detalhe ou estilo (N. do T.).

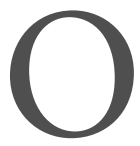

MOVIMENTO EPISTEMOLÓGICO QUE implicou a escolha, pela virologista Annalisa Malara, de enfrentar o desconhecido, a clareza experimental com que se expressa através da lógica consecutiva das três frases, apresenta um desafio paradigmático para as ciências humanas e as chamadas ciências exatas, além dos sistemas binários. Sua conclusão, "só me restava adentrar no desconhecido", é exatamente o que deve inspirar qualquer pessoa em sua área específica de pesquisa. E no desconhecido que todos entramos ou pelo menos certamente eu já tinha antes do vírus. Em minha pesquisa antropológica, usei os termos: encontro com o estrangeiro, diálogo com o estranho, observar o inexplorado. No entanto, o desconhecido é mais poderoso. Não é por acaso que a relação entre o familiar e o estrangeiro, cenário clássico da pesquisa etnográfica, se transformou, ao longo do tempo, em relações mais complexas em que essas diferenças, que outrora eram claras, agora se interpenetram reciprocamente e muitas vezes se invertem. $\mathrm{O}$ desconhecido é o desafio que pode ser enfrentado a qualquer hora e lugar. E essa incógnita também diz respeito à pesquisa antropológica, filosófica ou como se queira chamá-la. Emerge do desafio ao desconhecido, o método indisciplinado ${ }^{1}$.

A etnografia como pesquisa de campo se delineia vagando entre o objeto, o sujeito e o método. O que é classificado como "objeto" entra no método e se deforma no decorrer da pesquisa: o objeto vago acaba sendo um sujeito em trânsito, enquanto o método percebe que está vagando no indisciplinado. A divisão do conhecimento em disciplinas-disciplinadas, tal como foi estabelecida pela divisão do trabalho da era industrial, dividida em faculdades, departamentos, currículos etc., se dissolve no ar de pixels. O etnógrafo se move deslocado com uma lentidão abandonada (surrender), atento aos menores detalhes nas paisagens alteradas que fluem; ao refletir sobre tudo o que é vago, aprende a se observar durante a pesquisa. No processo do método reflexivo, o pesquisador se descobre parte da pesquisa. Prosseguindo no vagar, desenha-se um corpo-d'occhio ${ }^{2}$. O aprendizado contínuo e necessário baseia-se em ser-visto, ser-olhado, ser-olho que vê e é visto. A visão mutante e reflexiva do olhar, não o banal mostrar-se... Afirma-se a dimensão biocultural do olho e de suas histórias, cuja pupila - acariciada e umedecida lentamente pelas pálpebras - emerge em suas mutações e 
reflexões contínuas, determinadas pelo entrelaçamento, pelas relações, conflitos entre a cultura analógica e a comunicação digital. A indisciplina do método etnográfico incorpora tanto a polifonia evasiva do objeto-outro, que se revela como sujeito, quanto a ubiquidade inquieta da própria subjetividade fragmentada. É um trânsito errante e reflexivo que se move entre uma alteridade desconhecida e o eu alterado: desnuda-se a inconsistência da dicotomia sujeito/objeto, que é cogerada processualmente. Afirma-se o espanto indisciplinado que descobre a expansão da individualidade não só ao estrangeiro tradicional, mas também aos animais, aos vegetais, aos minerais e até ao que se denomina mercadoria ou, melhor, facticidade.

A vagância do método e o vagar do etnógrafo se misturam entre sincretismos culturais, polifonias narrativas, subjetividade ubíqua, diásporas inquietas, fetichismos "meta". Essa é minha constelação.

Por sua vez, todo pesquisador que vaga se torna um etnógrafo, no sentido de que ao vagar se encontra o estranho, absorve o diferente, percebe o perturbador, se sente fracasado. Ao deslocar as percepções "normais", são reunidos fragmentos irredutíveis entre si para expor a linguagem sincreticamente, ignorando o canto de sereia da síntese e da morte dialética. No meu vagar etnográfico, traço uma constelação transitiva e temporária, na qual transcrevo conceitos inquietos cuja composição (a "partitura") delineia a coexistência de metodologias variáveis e indisciplinadas. Nas marcas da partitura, fica mais claro esse mapa desorientado, para identificar os nexos entre meta-fetichismos e meta-morfoses.

A fisionomia é um conceito corporal posterior que se aplica no encontro com diferentes subjetividades (estrangeiros, coisas, minerais etc.). $\mathrm{O}$ traço fisionômico é uma configuração visual que absorve o "caráter" emocional de qualquer objeto que se transfigura em sujeito ao se oferecer ao encontro.

A meta-morfose da fisionomia meta-fetichista assinala a iniciação nas utopias ubíquas. Se a utopia não está em lugar nenhum e a ubiquidade em todos os espaços, a pesquisa etnográfica transita in-between nesse limiar iniciático e chega à confusão das ubiquidades utópicas. A comunicação digital está transformando a clássica distinção de espaço-tempo, favorecendo a expansão de experiências descentralizadas e não lineares de espaço-tempo. Afirmação comum é que a web é ubíqua e, portanto, a ubiquidade caracteriza as relações humanas e não humanas no espaço-tempo da internet. A própria identidade do sujeito etnográfico e de suas obras é ubíqua. Transita simultaneamente em espaços-tempos diversos nos quais o sujeito flutua e perde - felizmente - a identidade fixa, compacta e imutável. A identidade fixada.

As potencialidades internas ao processo etnográfico aspiram a estabelecer relações não antropocêntricas entre o corpo-morto e o corpo-vivo (body-corpse), 
sagrado e cotidiano, sexo e ótica, trabalho e arte. O meta-fetichismo incorpora o desejo de vivificar fragmentos culturais além dos dualismos conceituais, das reificações industrialistas ou da dialética sintética: o fetiche libertado do estigma colonial, continuado com o Iluminismo, acentuado pelo marxismo, freudismo e senso comum ("fetish"), atinge o corpo-d'occhio de uma antropologia comunicacional em que sente as relações entre mito e razão, corpos e coisas, estrangeiros e familiares: e as resolve. O meta-fetichismo é uma visão pragmática em direção a uma antropologia não antropocêntrica, na qual o humano não é mais o centro das cosmologias que dominam e controlam e usam o resto ("natureza"), para tentar a possível pacificação coevolutiva entre os seres humanos, animais, plantas, minerais. E até divino...

Entre meta-fetichismo e meta-morfose subsistem desejos transculturais, desvios subterrâneos, expressões inéditas que flutuam e se mesclam nas diferentes culturas com modelos irredutíveis. A imaginação exata do meta-fetichismo explora uma antropologia não antropocêntrica em que coisas, bens e objetos (as "facticidades") são liberados de serem apenas úteis, para poderem se transfigurar em corpos fisionômicos além do humanismo.

Muito, muito frequentemente, uma posição de "esquerda" se configura num sentido antirritualista. Eu mesmo sou há muito crítico, cético, indiferente tanto aos ritos populares arcaicos quanto aos - digamos - mais históricos ou contemporâneos. Apesar da minha formação antropológica, ou talvez precisamente por isso, sempre procurei me distanciar dos rituais. Creio que minha formação filosófica e política favoreceu meu distanciamento. Os ritos são estudados, mas não praticados, pelo contrário, escapam... Esse meu posicionamento começou a vacilar com as fissuras de uma determinada política (a minha) e com o impulso para reiniciar as pesquisas de campo. Dessa forma, pude participar e refletir sobre alguns ritos que mudaram profundamente o sentido de estar no mundo, em especial o funeral Bororo, em Mato Grosso (Brasil). A atração irresistível do rito une por um momento muito determinado e dramático não só todas as diferenças internas e conflitos externos, mas também todos os mortos de todos os tempos que se reúnem e se misturam com os vivos que choram, dançam e cantam. No rito, o tempo para e se expande a todos os "cantos" da aldeia, transfigurando todo lugar simbólico em espaço cosmológico. O rito é uma eternidade no tempo.

$\mathrm{O}$ aumento irresistível do vírus mudou essa perspectiva antirritualista. A minha experiência é baseada em uma solidão-não-solitária, na qual a força momentaneamente unificadora do rito está ausente. Estabele-se uma espécie de ritual-sem-rito. Comecei a praticar todas as manhãs, desde que estou autorrecluso, minirrituais individuais diários que enfrentam e desafiam o vírus, 
praticando a conectividade digital além do coletivo analógico. Um bom paradoxo. No entanto, essa escolha me fez sentir vivo, reuni palavras e conceitos, tentei expressar visões que não pertencessem apenas a mim. Em suma, a doença viral grudou em mim e - quase num ritual homeopático, cujas minipílulas tomo com sarcasmo - assimilo o vírus, incorporo-o, para tentar cancelar sua fria pretensão de me separar do mundo, do amor, da amizade, dos afetos, do desconhecido...

A experiência dramática que estamos vivendo favorece ainda mais a inserção no cotidiano da identidade ubíqua. Paradoxalmente, ao estar preso em casa, tudo o que acontece lá fora me envolve e às vezes me oprime. Conecto-me com o Brasil duas ou três vezes ao dia, leio jornais em quatro idiomas diferentes, ouço o noticiário, vejo séries, troco mensagens com pessoas que adoro, que são amigas e até desconhecidas: enfim, essa imobilidade forçada favorece uma ubiquidade livre. E minha "personalidade" (ou se quisermos "identidade") não pode ficar parada, imóvel, fixa, mas deseja ser transitiva, fragmentada, diaspórica (e também meta-fetichista, sincrética e polifônica!)... Estou sentado na frente do PC e, no mesmo tempo-espaço, movo-me para todo o lado. A solidão-não-solitária e a onipresença. Esse é o desafio... Muitos dos problemas atuais (fakes, odiadores, milenistas etc., mas também os humanistas-antropocêntricos) derivam, em minha opinião, da excessiva rapidez com que nos encontramos diante de uma acepção outra e alterada de ubíquo - uma ubiquidade viralizada e "viajada" pelo digital. Não mais o olho do deus cristão que vê e julga em todos os lugares, a ubiquidade da identidade vive nas práticas de cada um de nós (ou pelo menos em mim), com métodos, estilos, resultados desiguais. Posso respirar o mundo não porque sou o mundo, mas porque vivo ubiquamente... Talvez seja possível desenvolver uma solidariedade ubíqua e, portanto, afetuosa, terna, frágil e, também, sensual, lúdica e dramática.

\section{UBIQUIDADE}

Ubiquidade é um conceito que "encontrei" em um contexto distante. Morei e dei aulas no Brasil, em São Paulo, e com uma arfante regularidade voltava pelo menos duas vezes por ano a Roma, que era a minha cidade. Conversando com amigos entre as duas metrópoles, percebi que minha experiência subjetiva passava por um processo em que o espaço (entre dois continentes) e o tempo (entre fusos horários) estavam mudando seu padrão tradicional. Já havia sentido isso no cotidiano afastado dos anos 90 do século passado, mas só com a plena afirmação do digital tudo mudou de relevo. Descobri que minhas experiências estavam se tornando ubíquas e transformando os relacionamentos entre mim e os outros. Não só isso: mesmo dentro de mim as coordenadas do espaço-tempo 
mudaram, deixando-me mais desorientado do que o normal, e até a minha identidade acelerou as flutuações, apesar da minha opção por viver com lentidão. A partir dessa experiência, que poderia definir indevidamente uma etnografia-de-si, comecei a refletir sobre possíveis modificações mais gerais, que não eram só minhas; talvez um mal-estar de excesso de identidade nas conexões pudesse conter aspectos problemáticos, delineando uma subjetividade conectiva. De qualquer modo, posso defender que foram minhas experiências pessoais iniciais que me fizeram pensar se algo estava mudando no clássico tema da identidade.

Com essas premissas, que amadureceram tanto de forma indistinta quanto problemática, dentro e fora de minhas flutuações subjetivas, fui convidado a participar de uma conferência que parecia me aguardar na brecha entre salvação e risco. Foi também um sinal do destino, uma vez que que o tema do seminário internacional organizado pelo Instituto de Estudos Avançados da Universidade de São Paulo (IEA-USP) - justamente naquele evento os dois anos como professor visitante expiraram- era o tempo. E era também a oportunidade que esperava, ou melhor, que me esperava como um assaltante na passagem de um desfiladeiro ameaçador. A escolha foi quase obrigatória e por isso apresentei o relatório com um título seco: Ubiquitimes, e um subtítulo mais explícito: The ethnographic experiences of digital cultures and the syncretic mix of spacetimes (As experiências etnográficas das culturas digitais e a mistura sincrética de espaço-tempos).

Recupero uma parte do abstract para mostrar afinidades e diferenças com minha posição atual:

Meu artigo apresentará uma perspectiva antropológica do tempo a partir do conceito-chave de ubiquidade: ubiquitimes. As culturas e a comunicação digital vão transformar a distinção clássica de espaço-e-tempo, favorecendo experiências descentralizadas e não lineares de espaços-tempos. Um forte uso metafórico desse termo tem ocorrido recentemente na cultura da web. Uma afirmação comum é que a web é ubíqua e, portanto, a ubiquidade caracteriza as relações espaço-temporais (human and not-human) da internet. Ubiquitimes também amplia uma incessante elaboração de conceitos sincréticos e métodos polifônicos na cultura digital. Discutirei as diferenças entre os conceitos tradicionais de vanguarda de simultaneidade e o teológico de ubiquidade. Em seguida, apresentarei a emergência digital e os diferentes significados contemporâneos da ubiquidade como interconexões e interseções imanentes em tempos e espaços. Ubiquitimes representam uma imanência lógico-sensorial de caráter material/imaterial; expressam tensões além do dualismo hegemônico ou da ratio dicotômica regressiva. Ubiquitimes são a potencialidade da estrita imaginação conectada à vida digital 
diária. Selecionarei alguns casos empíricos a fim de demonstrar minhas hipóteses sobre experiências autogerativas de tempos ubíquos (ubiquitimes) em diferentes culturas e pessoas: uma divindade grega mítica (Kairos), uma publicidade da Swatch, um ritual funerário Bororo, uma arquiteta pós-euclidiana (Zaha Hadid) e, por fim, as experiências subjetivas com as tecnologias digitais (multividual). (Canevacci, 2015, p. 1)

O método expositivo indisciplinado é uma continuidade dessas proposições, pois se baseia em conceitos sincréticos de diferentes culturas e composições polifônicas, experimentando escritas etnopoéticas, não ficcionais, sonoras e visuais. A escolha foi (e continua a ser) baseada no cruzamento da dimensão não linear do tempo com a flutuante do espaço, cujo resultado foi sendo definido, precisamente, ubíquo. Desde essa época faço pesquisa sobre esse conceito, que modificou a sua versão tradicional devido à afirmação daquelas tecnoculturas que conhecemos bem (smartphones, redes sociais, WhatsApp etc.). No entanto, algumas perspectivas mudaram, principalmente devido àquele excesso de entusiasmo construcionista-propositivo com que se constituía.

Em todo caso, a ubiquidade é o conceito central-descentrado e igualmente problemático que emerge transformado em seus significados tradicionais. A mudança de sentido da palavra é determinada por um sujeito que, inserido nos fluxos da comunicação digital, vive o cotidiano em que as coordenadas clássicas de espaço/tempo se mesclam e se transformam. A aceleração de identidades ubíquas apresenta um dos grandes acontecimentos do novo milênio a ser analisada por meio de uma etnografia indisciplinada. Já por volta de 1990, artistas e curadores conectaram a fase pós-industrial com a pós-humana, a partir da qual se estabeleceram as primeiras identidades múltiplas em sentido digital (Documenta X, 1997). Essa relação com as artes pós-humanas é importante, mas muito parcial e autorreferencial. Na verdade, já em 1988, Mark Weiser havia antecipado esse processo com base na ubiquitous computing, afirmando que a ubiquidade que caracterizava as relações espaço/tempo na comunicação digital envolvia humanos e não humanos. O paradigma dicotômico tradicional entre ser humano (anthropos) e bens, coisas, objetos não humanos, estava se dissolvendo no ar dos pixels, parafraseando uma frase famosa de Marx e Engels. Essa questão questiona o antropocentrismo tradicional da cultura ocidental, como será visto através do conceito-chave de meta-fetichismo, para libertar o fetichismo clássico daqueles depósitos sedimentados em seu "corpo" pelo colonialismo, iluminismo, marxismo, psicanálise até o senso comum atual.

Sempre seguindo Weiser, pioneiro da oubiquidade digital: 
A ubiquitous computing define a terceira onda do computador. Antes, havia mainframes (sistemas centrais), cada um compartilhando, mas por muitas pessoas. Estamos agora na era do computador pessoal, pessoas e máquinas não convivem facilmente entre si no desktop.... Em seguida, vem a ubiquitous computing. (Rutgers University, 1996/2010, 34:06)

Mark Weiser encara uma perspectiva ainda mais perturbadora, talvez influenciada pela ecologia da mente de Gregory Bateson: "O computador pode estender seu inconsciente” (Rutgers University, 1996/2010, 43:24). Bateson (1976) já criticou a conhecida distinção freudiana entre ego-id-superego, por afirmar que o ego se expande fora do sujeito a partir dos canais de comunicação: por isso o conceito de mente se expande e flui entre humanos, florestas de sequoias ou anêmonas do mar. Esse modelo ecológico de comunicação - bem diferente das banalidades ambientalistas dominantes - cruza e mistura as tradicionais distinções entre humano e não humano. A natureza para ele é um ser vivo que troca informações mentais com todas as criaturas por meio de tecnologias, seja uma roda, seja um chip. Nesse sentido, o sagrado (não a religião!) é a trama imanente que conecta cosmologicamente todo ser: e por ser se deve entender uma pedra, uma árvore, uma criança, uma borboleta. Os mundos mineral, vegetal, animal e humano estão conectados em uma concepção mental que não é mais antropocêntrica, mas expandida e baseada em trocas informacionais entre as várias partes vivas. A dicotomia orgânico-inorgânico é superada por meio de uma perspectiva neoanimista que prefiro definir como meta-fetichista. É por isso que Norbert Wiener convidou Gregory Bateson e Margaret Mead para o grupo de estudiosos que inventaram a cibernética. A aliança inicial entre informática e antropologia - geralmente rejeitada ou ignorada - se deve à cismogênese, que tinha elementos em comum com o feedback: o primeiro conceito foi elaborado por Bateson em sua pesquisa sobre o ritual Naven entre os Iatmul na Nova Guiné (Bateson, 1988), onde pode ou não ocorrer uma divisão - retroativa - entre grupos de pais.

Atualmente, as consequências segundo as quais o inconsciente se expande na tela do computador - mesclando os impulsos visuais entre skin e screen - são experiências cotidianas verificáveis: as estatísticas veem os cliques hegemônicos na teologia e no YouPorn, dos quais derivam as prováveis expansões de ressentimentos ilimitados, fakes inverificáveis, haters incontroláveis. Nessas reflexões, é importante seguir Tim Berners-Lee (2017), inventor da web, no CERN, e ainda uma das pessoas mais avançadas e críticas da internet:

Precisamos de mais transparência algorítmica para entender como as decisões importantes que afetam nossas vidas estão sendo tomadas, e talvez um conjunto 
de princípios comuns a serem seguidos. Precisamos urgentemente tapar o "ponto cego [blind spot] da internet" na regulamentação das campanhas políticas. (para. 9)

A revolução digital e a aceleração da pragmática comportamental estão prefigurando identidades ubíquas que podem produzir resultados problemáticos, não só pela beleza de cruzar os limites do espaço/tempo em um processo libertador e multiplicativo da própria subjetividade, mas também pela perda das certezas territoriais de si que provoca a expansão dos microrracismos, dos tempos perdidos e dos espaços purificados. As consequências apresentam cenários ambíguos e conflitantes que resumo assim: O sujeito cosmopolita é livremente ubíquo e coexiste com as regressões da personalidade digital-autoritária. Essa conclusão é diferente do meu primeiro relatório sobre o ubiquitime: um foco no realismo negativo me forçou a fazer essa revisão dramática três/quatro anos após a primeira conferência.

Trata-se, portanto, de enfrentar esse desafio etnograficamente para tentar resolvê-lo de forma progressiva e libertadora, sem perder de vista a complexidade das conclusões posteriores, indiferenças, preconceitos, racismo que cada pessoa investe na sua própria moralidade anômica. A moralidade de um povo inteiro ou de uma pequena comunidade é baseada em valores (costumes) compartilhados pela maioria e que mudam ao longo da história. A anomia é a ausência de regras (nomos) que se acentuam durante as transformações do cotidiano. A aliança digital entre anomia e moralidade é uma das causas da atual desconexão na solidariedade pública e privada, que, em vez de caminhar para o suicídio individual, cria uma massa crescente - autoritária e irregular que imagina ter uma moralidade superior a defender. As "patologias normais" psicoculturais com as relativas implicações sociopolíticas estão aumentando à medida que os estilos de comunicação estão transformando as distinções clássicas de espaço-tempo e de público-privado. $\mathrm{O}$ digital permeia diferentes comportamentos e favorece experiências não lineares de tempos-espaçados ou, como sugeri antes, de ubiquitimes, que libertam e envolvem, emancipam e desfiguram as sincronicidades ambíguas de um sujeito exausto.

O conceito de ubíquo movimenta indisciplinas e estabelece relações privilegiadas entre culturas sincréticas e tecnocomunicação. Sem refazer a história desse conceito, destaco que é imanente à ubiquidade não ficar parada nem mesmo diante de si mesma. Na tradição ocidental, o conceito de ubíquo tem uma matriz "espiritual" ligada à teologia cristã que simboliza no olho triangular o divino por meio do qual Deus Pai observa você em todos os lugares. Essa teologia observadora imprime uma marca totalizante que anula o privado por meio do controle visual erga omnes. Graças à ubiquidade teológica, a condição humana 
é observada, julgada, condenada, pois o pecador não escapa escondendo-se, já que "o olho divino" é ubíquo, sempre o observa e o transcende.

Ao abordar o uso contemporâneo da ubiquidade, é necessário realizar uma breve digressão sobre o cronotopo de Bakhtin (1988) e a simultaneidade dos futuristas. $\mathrm{O}$ significado atual de ubíquo expande o de cronotopo elaborado pela crítica literária. A sua matriz científica - no sentido das chamadas ciências exatas - foi transformada por Bakhtin em uma metodologia a ser aplicada nos romances do século XIX. O cronotopo une aquilo que foram os a priori e que alguns escritores utilizam na escrita em que o espaço-tempo apresenta uma dinâmica unificada ou construída. Dessa forma, o autor multiplica as implicações psicológicas e dialógicas em cada personagem, enquanto o herói deixa de ser uma projeção do autor a quem todos os outros personagens estão subordinados. Em suma, o cronotopo é um pré-requisito para o desenvolvimento descentralizado da polifonia literária analisada em Dostoiévski, na qual as subjetividades se multiplicam em suas individualidades específicas e irredutíveis. Consequentemente, se o herói não é mais a projeção monológica do autor, cada personagem pode desenvolver sua própria autonomia linguística e psicológica. Isto é, polifônica.

Um conceito afim ao cronotopo é a simultaneidade. Sabe-se que os futuristas afirmaram e amaram esse conceito, aplicando-o tanto nas artes plásticas (pintura e escultura) quanto nas artes cênicas, nas quais as declamações de poemas, músicas e histórias eram apresentadas simultaneamente nos palcos. Essa opção expressiva é de interesse fundamental para o meu discurso: os futuristas foram os primeiros que, como vanguardistas, amaram a metrópole em oposição ao tédio do campo e do luar. De La Città che Sale (Boccioni, 1910-1911) emergem panoramas dissonantes, extensões corporais, fricções ruidosas: enfim, todas aquelas sensorialidades que determinam simultaneamente a experiência tecnourbana desde o início do século passado.

A simultaneidade também é filha do nascente cinema, que, na montagem, exprime uma contiguidade ótica entre segmentos narrativos diversos. Para os futuristas, a simultaneidade é uma experiência estética feita de enxertos fragmentados entre metrópoles e máquinas; uma pulsação expressiva de imagens ou "palavras livres" da consecutio clássica, que é possível graças a um sujeito igualmente simultâneo: o futurista. É aquele que tem a subjetividade treinada para apreender a flexibilidade visionária entre espaços-tempos vividos nas paisagens urbanas. Essa perspectiva simultânea é a arte para um futuro anunciado nos movimentos maquínicos, icônicos e sonoros que surgem na rua, atravessam a janela do ateliê e se posicionam na tela do pintor ou na partitura do músico. Simultaneamente.

Atualmente, a ubiquidade digital exprime tensões além do dualismo material/imaterial, ainda presente na simultaneidade futurista. Daí as possibilidades 
ubíquas-polifônicas-diaspóricas-sincréticas-fetichistas que expressam uma oposição além do binário, funcional para trazer a condição humana de volta ao domínio de uma ratio dicotômica. Ubíquo é incontrolável, incompreensível, indeterminável. As identidades ubíquas poderiam sair do controle político vertical, da racionalidade monológica, de uma fenomenologia linear.

Ubiquidade é a imaginação precisa que une ou cruza culturas híbridas, artes visuais, comunicação digital; seu aspecto identitário lida com os restos ou traços daqueles sujeitos que reivindicam passados perdidos e infâncias nunca reencontradas.

Essa afirmação - uma modificação construcionista - ainda exprime minha posição atual. Mencionei que a própria identidade do pesquisador não permanece idêntica a si mesma, pois realiza relações diagonais em contextos diferentes. Essa identidade é mais flexível do que no passado industrial, é uma identidade que oscila entre tempos-espaçados que se movem dentro e fora do enquadramento (frame) do sujeito. Assim, mesmo o olhar etnográfico deve se tornar ubíquo para decodificar a coexistência de códigos discordantes (escritos, visuais, musicais, mistos) e praticar narrativas igualmente diferenciadas por meio da composição polifônica. O pesquisador se coloca nessa situação ubíqua em suas vivências cotidianas com o outro, mesmo em um contexto nativo; portanto, esse outro é igualmente ubíquo, no sentido de que vive onde seu sistema de comunicação digitalizado está ativo naquele momento. Essa experiência não significa a desmaterialização das relações interpessoais. Também. Basicamente, atesta uma complexa rede de conexões psicocorpóreas, ópticas e manuais, cerebrais e imaginárias que movimentam a aparente imobilidade do sujeito. As óbvias implicações psicológicas exigiriam pesquisa específica, junto com a autopesquisa do sujeito-etnógrafo que vivencia em si mesmo essas mutações aceleradas. O conceito de multivíduo se manifesta nessas conexões: a etnografia ubíqua expande um sujeito conectivo, por meio de fragmentos temporários nos quais é desidentificado o eu "normal".

As trocas entre as diferentes culturas, que no passado foram vistas e analisadas como a dissolução de culturas "débeis" - estrutural e tropicalmente tristes por serem destinadas à entropologia (Lévi-Strauss) - crescem de acordo com misturas ativas caracterizadas por sincretismos polifônicos e não por aprovações passivas. O etnógrafo não é mais o único pesquisador formado a partir de procedimentos estáveis na pesquisa de campo: porque, por um lado, o campo se expandiu para a simultaneidade digital; e, por outro lado, tornou-se a autorrepresentação por parte de sujeitos nativos que afirmam sua própria cosmologia autônoma.

A ubiquidade cultural e identitária conecta a aldeia e a metrópole. Um antropólogo inovador como George Marcus (1995) desenvolveu o conceito 
de multi-sited ethnography, com o qual enfatiza que a pesquisa empírica atual não é mais, como no passado, centrada em um único território (por exemplo, a aldeia), mas flui incessantemente entre contextos diversos, entre aldeia e metrópole, entre códigos e lugares outrora separados estruturalmente e que agora se cruzam, simultâneos e sobretudo ubíquos. Qualquer pesquisa etnográfica de campo enfrenta um cenário cultural-comunicacional não mais baseado na fixidez localista, mas em fluxos multi-sited, ou seja, os diferentes sítios (no sentido de lugares) são atravessados pelos sites (no sentido de redes sociais). Em minha experiência pessoal, fiz pesquisas de antropologia urbana em São Paulo e pesquisas etnográficas com os Bororo. Então descobri que as relações entre uma grande metrópole como São Paulo e uma pequena aldeia como Meruri (Mato Grosso) estavam tão conectadas por tecnologias digitais (computador, tablet, TV, iPhone) que era impossível separar os espaços, mesmo durante o supremo ritual fúnebre (ver Canevacci, 2018; Marcus, 1995).

\section{DIÁSPORAS}

As biografias de Edward Said e Daniel Barenboim são um manifesto vivo de sincretismos culturais e subjetividade ubíquas. Seu diálogo polifônico sobre música, política e histórias de vida é um testemunho que afirma visões alternativas de mundo (Barenboim \& Said, 2004). Eles refletiram, ensinaram e musicaram nos mais diferentes países com o objetivo de cruzar a fluidez cultural e se identificar contra e além de qualquer endogamia fundamentalista. Além disso, praticaram o desejo de construir ubiquidades de espaço-tempo e descobrir diferenciados "Oriente"/“Ocidente" nas experiências cotidianas. A perspectiva etnográfica deles antecipa críticas às soberanias ou racismos atuais, sem nunca aceitar essa "imaginária” dicotomia geopolítica e para explorar itinerários estéticos desconhecidos. A condição exilada de Said - autodefinido como "expatriado transcendental" - permitiu-lhe abrir o campo dos cultural studies. E a filosofia da música de Barenboim forjou as condições de um sujeito cosmopolita. Seguindo o diálogo entre eles, o conceito de diáspora é expresso de um modo divergente e paralelo.

Edward Said incorporou uma tensão transitiva entre a diáspora individual e a identidade exilada. Por isso, suas reflexões são significativas: experiências subjetivas e teorias gerais se conectam na elaboração de visões críticas que desafiaram a ordem disciplinar acadêmica e afirmaram estudos culturais inovadores. Ele mesmo lembra - 25 anos após a primeira edição de Orientalism - que

os modos como uma obra sobre as representações do "Oriente" se presta a uma representação crescente e a interpretações errôneas .... O desejo humano e humanístico 
do iluminismo e da emancipação não é facilmente adiável. Gostaria de acreditar que o Orientalismo teve um lugar na longa e frequentemente interrompida rota para a liberdade humana. (Said, 1979/2003, pp. XV-XXX)

Daniel Barenboim (2007) escreveu sobre o poder da música a partir de uma perspectiva de que tudo está conectado com tudo. A trama que conecta (the pattern which connect) é um método antropológico e uma visão ética que se estabeleceu com a pesquisa mencionada de Gregory Bateson. Assim, uma metodologia ubíqua e indisciplinada consegue conectar um crítico literário, um músico regente, um antropólogo errante. O poder da música não se restringe a uma arte específica, obviamente a inclui e a transcende por meio de problemas sociais e humorais de sua época e de algum futuro possível. Barenboim cita o exemplo do late style em Beethoven, que também é o título de um livro de Said (2006), no qual afirma possíveis experiências estéticas ainda não escritas, vistas ou ouvidas. A inspiração para o título e a filosofia composicional relacionada foi retirada de um fragmento de Adorno (1937). Said (2006) segue essa visão quando afirma que "explorar a experiência do late style implica uma tensão não harmoniosa e agitada e, acima de tudo, uma espécie de deliberada produtividade improdutiva que vai contra ela" (p. 7). Essa unproductive productiveness pode fomentar a crise relacionada à reificação da escuta e da razão instrumental.

Um compositor "exilado", como Beethoven, e um filósofo "negativo", como Adorno (1955, 1966), continuam a explorar figuras musicais dissonantes, imagens de narrativas desconhecidas por meio de Barenboim e Said. Entre sons inauditos e conceitos ubíquos, esses quatro autores vivenciaram o exílio de maneiras diferentes. O estilo definitivo é alcançado quando o autor se sente livre de qualquer vínculo institucional ou regulatório: nessa condição imaterial, a criatividade não tem limites históricos, harmônicos ou estéticos. O late style ilumina e o autor é conduzido por caminhos desconhecidos onde qualquer síntese conciliatória é rejeitada. Nesse sentido, Said (2006) escreve:

Para Adorno, muito mais do que quem falou das últimas obras de Beethoven, aquelas composições que pertencem ao terceiro período do compositor ... constituem um acontecimento na história da cultura moderna: um momento em que o artista que domina totalmente o seu meio, no entanto, abandona a comunicação com a ordem social estabelecida da qual faz parte e estabelece uma relação contraditória e alienada com ela. As suas últimas obras constituem uma forma de exílio. (pp. 7-8)

Em Paralelos e Paradoxos (Barenboim \& Said, 2004), o diálogo entre Said e Barenboim é exemplar no método, na perspectiva político-cultural, nas conexões 
entre diferenças identitárias. O próprio título contém o desafio de percorrer caminhos paralelos entre identidade, música, literatura, sociedade; e aceitar paradoxos a serem vividos em vez de resolvidos. A convergência entre paralelos e paradoxos é um paradigma exemplar para a construção de um humanismo ubíquo, sincrético e polifônico. Esses autores rejeitam as fronteiras políticas e as barreiras culturais: ambas são exemplos de uma filosofia dialógica aplicada ao seu contexto geopolítico específico. Said nasceu em Jerusalém em uma família palestina, foi criado no Cairo como árabe-cristão, frequentou escolas nos Estados Unidos, tornou-se professor na Columbia University. Barenboim nasceu em Buenos Aires em uma família judia russa, viveu no Estado de Israel e se tornou diretor das orquestras mais importantes de Berlim, Milão, Chicago. Juntos, eles imaginaram e executaram o projeto musical "The Palestinian West Bank", celebrando o $250^{\circ}$ aniversário de Goethe em Weimar, reunindo músicos árabes e judeus.

$\mathrm{Na}$ introdução, Barenboim (Barenboim \& Said, 2004) escreve sobre seu amigo Said, recentemente falecido: "Ele era uma daquelas raras pessoas que viam as conexões e paralelos entre as diferentes disciplinas" (p. 136). E o próprio Said sublinha no diálogo com Barenboim: "No seu trabalho como intérprete, Daniel, e no meu trabalho como intérprete de literatura e crítica literária, deve-se aceitar a ideia de deixar de lado a própria identidade para explorar o 'outro"' (p. 28). Esse sujeito posicionado representa o método antropológico e as práticas etnográficas que transitam aos estudos culturais: não é possível compreender o outro, mantendo fixa a própria identidade, comportamentos estáveis, conceitos repetitivos.

O diálogo entre Daniel e Edward reúne as possíveis convergências paralelas entre filosofia e etnografia, música e literatura, Oriente e Ocidente. Deste ponto de vista, a universidade e a orquestra são espaços onde as artes e as ciências exploram em vez de se conformar; e então, novamente seguindo Said (Barenboim \& Said, 2004): “O paradoxo é que a música, ao ser acessível, não pode ser entendida” (p. 37). Segue-se esta reflexão de Barenboim, que não tem apenas um interesse biográfico, mas uma declaração de filosofia errante: "Sinto-me alemão quando rejo Beethoven e italiano quando rejo Verdi" (Barenboim \& Said, 2004, p. 147). A música e a escrita estão em profundo diálogo com "meus" autores, cujo propósito se condensa nesta frase de Said: "a missão humanística deve ser capaz de manter as diferenças, mas sem aquela dominação guerreira que normalmente acompanha as afirmações de identidade" (Barenboim \& Said, 2004, p. 135). Esta distinção é importante, porque muitas vezes afirmar as diferenças pode significar legitimar a subordinação dos “outros”, em relação à identidade dominante. 
Em outro texto, Out of Places, Said (1999) constrói os seus espaços de memória e temporalidade: "junto com a linguagem, é a geografia - especialmente nos deslocamentos entre partidas, chegadas, despedidas, exílios, nostalgia - que está no centro das minhas memórias: Jerusalém, Cairo, Líbano, Estados Unidos" (p. 120). Esses movimentos criam um tipo de identidade mais fluida, múltipla, fragmentada, que o autor tenta transformar ou deslocar de uma potencial fraqueza do ego para um enriquecimento cosmológico do sujeito. No diálogo entre Said e Barenboim ocorre o encontro do político que extrai o poético e vice-versa graças ao cruzamento de suas identidades. E Said escreve: "Na minha opinião, é impossível no século XXI reivindicar com credibilidade uma única identidade" (Barenboim \& Said, 2004, p. 147). Ele mesmo destaca o problema da identidade em seu nome: Edward - "um nome ridiculamente inglês" - e Said "o nome de família inconfundivelmente árabe" (Said, 1999, p. 143).

Para ele, a identidade fluida é uma reflexão histórica biograficamente dada:

Acho que a identidade é um conjunto de correntes, fluindo, mais do que um lugar fixo ou um conjunto estável de objetos. Certamente sinto por mim mesmo . . . . Não só é possível ter múltiplas identidades, mas também, eu diria, é algo a se aspirar. $\mathrm{O}$ sentimento de pertença a diferentes culturas só pode ser enriquecido. (Barenboim \& Said, 2004, p. 23)

\section{POLIFONIAS}

A primeira vez que cheguei a São Paulo - em 1984 - o carnaval estava apenas começando. Não conhecia ninguém e sabia que as únicas duas pessoas cujos números de telefone tinha estavam fora da cidade. Todos os bancos estavam fechados (era uma quinta-feira) e só reabririam na semana seguinte. No Instituto Italiano de Cultura, na rua Frei Caneca, me deram a chave de um pequeno apartamento particular na mesma rua. Ignorava a possibilidade de fazer o "câmbio paralelo" com os dólares (uma troca paralegal também citada nos jornais) e por isso fiquei em dificuldades econômicas, não podendo ter cruzeiros. Fui ajudado pela mesma funcionária do Instituto Italiano, aonde voltei pouco depois para pedir dinheiro emprestado, a qual que me confundiu com um turista comum com problemas de dinheiro - como me confessou depois, ao ver, para seu espanto, minha foto na Folha de S.Paulo. Com aqueles poucos cruzeiros, que me salvaram de uma situação que era nova para mim, só pude "sobreviver" e com não poucas dificuldades.

A solidão em uma grande metrópole pode ser vivida de forma mais ou menos suportável, de acordo com a sensibilidade de cada um; mas quando toda 
essa metrópole é atravessada pela agitação carnavalesca que caracteriza o Brasil, ser excluído é simplesmente doloroso. A primeira coisa que comprei - e ainda tenho - foi o mapa da cidade. Mas isso, em vez de me ajudar, me confundia ainda mais: nunca teria imaginado a enormidade tamanha de São Paulo e, ao mesmo tempo, tamanha viscosidade. Cada mapa caracteriza a "sua" metrópole, mas aquela foi e é uma metrópole tão grande, que se sobrepõe e mistura pontos de referência de forma paroxística, de modo que a única coisa a fazer para um "estrangeiro" como eu, na época, com pouquíssimo conhecimento da língua portuguesa, só poderia ser (além da imobilidade) a perplexidade. Na verdade, o mapa da cidade em si era tão grande que o abrir na rua era impossível, além de inútil. Era como se o mapa coincidisse com o próprio território, em vez de ser uma sintética reconstrução simbólica: o que poderia me lançar no desespero ou, na verdade, na perplexidade. E me perder foi, mais do que uma decisão minha, um abandono aderente ao fluxo das emoções.

E é verdade que, se se perder em qualquer cidade é fácil, em São Paulo é simplesmente vertiginoso. Acostumado com a minha cidade - Roma - onde a única maneira possível de conhecê-la é percorrendo-a, resolvi usar a mesma "linguagem" e comecei a caminhar: foi assim que, errando, tentei mapear o território paulistano. Equívoco, porque São Paulo - como depois entendi - não é apenas vasta demais, mas é compreensível tanto em seu território público, quanto em seu espaço privado; e nas incursões, principalmente noturnas, de carro nas "rodovias internas". Público, privado, movimento são igualmente fontes de percepções cognitivas. Logo aprendi que essa "cidade grande" pode ser conhecida na alternância de três ritmos de comportamento e de controle de espaço-temporal: a quietude doméstica, a hipervelocidade noturna, a lentidão da caminhada solitária. Todas essas três dimensões desenvolvem muitos modos de observação, cuja intriga final constitui a rede por meio da qual é representado o fluxo metropolitano.

Ainda assim, em perspectiva, caminhar com o mapa nas mãos foi um equívoco útil, porque, ao contrário do Rio, a vida social na rua é pouca significativa - pois se dá preferencialmente em residências particulares fechadas, em shopping centers, nos locais que estão na moda ou em instituições culturais; então, comecei a observar como a cidade comunica com seus prédios, as ruas, as placas, as lojas, o caos do trânsito insaciável. Já a partir dessas notas, delineia-se uma cidade que se comunica com vozes diversas e todas copresentes: uma cidade que entoa um coro polifônico, no qual diferentes itinerários musicais, materiais sonoros ou ruídos ambientais agressivos se cruzam, colidem e se fundem, resultando em linhas de fuga harmônicas ou mais frequentemente dissonantes. A cidade mostra-se polifônica e dissonante desde sua primeira experiência. 
A impossibilidade de percorrer a pé grandes extensões do território metropolitano levou-me a selecionar algumas áreas a partir de uma perspectiva qualitativa baseada no estupor. Nestes locais escolhidos realizei olhares e caminhadas até elaborar as primeiras hipóteses de trabalho, a seleção de indicadores e até mesmo um método específico para representar a cidade, à medida que os códigos característicos de uma rua, de alguns edifícios ou de bairros inteiros ficaram claros aos meus olhos. Continuo convencido de que é possível desenvolver uma metodologia de pesquisa mais ou menos precisa sobre a comunicação urbana apenas com um pacto: querer se perder, gostar de se perder, aceitar ser estrangeiro, desenraizado e isolado antes de poder reconstituir uma nova identidade metropolitana. $\mathrm{O}$ desenraizamento e o estranhamento são momentos fundamentais que - mais súbitos do que predeterminados - permitem a escuta de misturas imprevisíveis e aleatórias entre os níveis racional, perceptivo e emocional, que só a forma-cidade pode combinar.

Muitas vezes, o olhar desenraizado do estrangeiro tem a possibilidade de apreender aquelas diferenças que o olhar domesticado não vê por estar muito fechado, muito habituado a um excesso de familiaridade. São precisamente as diferenças que constituem um extraordinário instrumento de informação que, selecionado, articulado e percebido de acordo com determinados critérios, pode contribuir para traçar um tipo diferente de mapa, por meio do qual são descritos os comportamentos da metrópole. A cidade em geral e a comunicação urbana em particular são comparáveis a um coro que canta com uma multiplicidade de vozes autônomas que se cruzam, se relacionam, se sobrepõem, se isolam ou se contrastam; consequentemente, a escolha metodológica é "dar voz a muitas vozes", experimentando uma abordagem polifônica para representar o mesmo objeto: a comunicação urbana. A polifonia está no objeto e no método. E é assim que o objeto presumido se mostra composto por muitos sujeitos urbanos com os quais se deve aprender a dialogar.

Cada fragmento desenvolve seu próprio tema, como um solista seguindo uma partitura musical; isso se articula de acordo com suas próprias regras e, ao mesmo tempo, é condicionado pelos desenvolvimentos melódicos de todos os outros. Do conjunto de vozes solo selecionadas - ensaios, letras, visuais, musicais, artísticos - deve resultar a "inspiração harmônica" da cidade, a sua capacidade de cantar com vozes diversas a partir das quais é possível elaborar - polifonicamente - a sua representabilidade. É característica da cidade a sobreposição de melodias e harmonias, dos ruídos e dos sons, regras e improvisações, cuja partitura - simultânea ou fragmentada - comunica o fluxo temporário da obra. Pela multiplicação de abordagens - olhares, timbres, vozes, caminhadas, sombras - será possível chegar perto do objeto/sujeito da pesquisa. Isso é a polifonia: uma narrativa composta de instrumentos interpretativas, cada uma diferente 
dos outros, mas convergindo para um paradigma inquieto. Uma narrativa que oscila entre abstrações urbanas e emoções perdidas; entre a seleção fotográfica e os códigos simbólicos, em busca de prédios falantes, ruas silenciosas, anúncios bizarros, árvores perdidas, alegorias mudas.

A "polifonia” foi o resultado mais importante dessa pesquisa empírica: uma antropologia da comunicação urbana a partir do método etnográfico de São Paulo. Aqui aprendi a estar no campo, a viver uma mistura de estrangeiro e familiar; observar cada detalhe com sensibilidade micrológica; rejeitar generalizações e estereótipos; perceber minhas as reações emocionais como parte da pesquisa; viver a solidão de se perder entre os fluxos da metrópole. Ficar sozinho na multidão é uma arte que te faz sofrer, te exalta, te entedia. A reflexividade impõe delicadamente seu método: o pesquisador fala e reflete sobre os diferentes e muitas vezes conflitantes eus internos, sobre as suas próprias identidades, que emergem descontroladas no campo.

O uso da câmera fotográfica tornou-se um multiplicador essencial de linguagens: tive que aprender a usá-la segundo critérios que as práticas ensinavam, e não pelos manuais. Escolher o enquadramento; refinar o olhar, tornar-se o olhar, olho que vê e se vê, apreendendo a menor diferença; nunca fazer anotações em campo; memorizar sempre as reflexões e depois escrevê-las em casa. Para evitar assaltos (ladrões), coloquei a câmera em um saco plástico banal, escolhi a cena para enquadrar, tirei rapidamente, fotografei e coloquei de volta no lugar. Assim - olhando, selecionando, fotografando - aprendi a dialogar com as tantas vozes que edifícios, ruas, placas, árvores, coisas me comunicam. Recentemente, fui criticado por essa escolha de não entrevistar pessoas. Porém, fui e continuo contra a entrevista sociológica por vários motivos e esse trânsito urbano me fazia sentir que as pessoas eram e são também edifícios, ruas, árvores: portanto, o meu diálogo etnográfico baseia-se na invenção de diálogos entre duas subjetividades por meio da interpretação de códigos visuais. Foi uma experiência alienante e estimulante discutir com a Pirâmide do Poder da Avenida Paulista, onde a Federação das Indústrias do Estado de São Paulo (Fiesp) administra a política financeira (mas também política: comandou o impeachment da presidenta Dilma Rousseff) de todo o Brasil, por meio de um modelo arquitetônico autoritário e uma densa grade de metal nas paredes, que torna o interior invisível. Fiquei maravilhado com um McDonald's em forma de igreja medieval, com uma entrada circular em forma de hambúrguer, ao lado uma verdadeira torre com o clássico " $M$ " em vez de sinos; interroguei uma seringueira majestosa e solitária sobre o motivo do ressentimento generalizado dos cidadãos contra as árvores. E posso dizer que meus amigos paulistanos me confessaram que não tinham refletido sobre os detalhes para eles tão familiares da cidade. 
O meu olhar estrangeiro se refinava com o espanto: outra reação que se transformou em método: o estupor metodológico. Aprender a maravilhar-se significa que todo o meu corpo podia colocar-se numa dimensão porosa, aberta ao desconhecido, ser atravessado por códigos surpreendentes, nunca imaginados, completamente alheios às minhas experiências e por isso desejadas por mim. Sem que o tenha definido durante ou após essa primeira pesquisa, o estupor metodológico passa a fazer parte das minhas "técnicas" de auto-observação. Confesso que já considerei uma das minhas características habilidosas e meticulosas a capacidade de saber observar. No entanto, o contexto diferente desafiou a minha, ao menos imaginada, capacidade. Portanto, observar-me-observando tornou-se mais um jogo de espelhos no qual tinha que flutuar sem poder assumir a perspectiva clássica, objetiva e monológica da disciplina. Uma ansiedade indisciplinada levou-me a misturar pontos de vista, artes visuais e ciências urbanas, literatura e cinema, publicidade e design. Foi durante esse processo empírico que emergiram os dois conceitos decisivos e inesperados da pesquisa: polifonia e sincretismo; o terceiro - ubiquidade - surgiu nos últimos anos. O fetichismo me acompanha desde que era estudante e a diáspora é a bússola quebrada por minhas muitas viagens ao Brasil.

Polifônico foi o adjetivo determinante que qualificava a pesquisa a ser narrada não mais com uma só voz, um único estilo, um monologismo linguístico. Tentei conectar a multiplicidade de códigos que a comunicação coloca em cena, suas diferentes vozes, muitas vezes opostas e ainda mais caóticas: essa é a composição narrativa que mais me atrai. Se o contexto empírico da pesquisa expressa dissonâncias polifônicas, deve-se desenvolver uma constelação igualmente polifônica e dissonante. A dissonância, de fato, favorece não apenas a criatividade cultural, mas também cognitiva: além das supostas harmonias musicais e sociológicas, muitas vezes indicadoras de tendências autoritárias.

Mikhail Bakhtin - o ensaísta soviético a despeito de si mesmo - escreveu o referido ensaio que influenciará uma parte dos antropólogos a partir da década de 1980. O sucesso da polifonia em uma parte (minoritária) dos antropólogos é claro: mesmo os textos clássicos da disciplina têm uma única voz solo (o antropólogo que escreve), enquanto as vozes dos outros estão ausentes: informantes ou nativos. Os textos acadêmicos estão cheios de páginas em branco onde vozes, emoções, entonações, dialetos ou línguas desapareceram, até mesmo a presença do outro. O autor e o herói se unem na figura do antropólogo. Ele é o narrador de si mesmo e o herói de sua história. Essa estrutura hierárquica da escrita em relação à pesquisa é parcialmente evaporada graças a Bakhtin e Said: dois críticos literários que abrem as ciências humanas. 


\section{SINCRETISMOS}

As pessoas perguntam: "O que você prefere, 'indio' ou 'nativo americano?? $\mathrm{Ne}$ nhum é aceitável, nem qualquer versão da palavra "Cherokee". . . A palavra Cherokee para Cherokee é "Ani Yunh Wiya". Se traduzida literalmente pode significar

O Povo, como tantas outras nações indígenas nomeiam a si mesmas. Nenhuma das palavras pelas quais você nos chama são palavras pelas quais nós chamamos a nós mesmos. (Durham, 1993, p. 124)

O sincretismo era uma palavra "exótica” para mim, apesar da origem grega. Gostava do som: apenas pronunciá-la evocava algo misterioso e concreto. Assim que chegou ao Brasil, tornou-se um conceito precioso e em práticas vividas cotidianamente nos mais diferentes contextos e com os mais diversos significados. Na travessia - como foi definida a viagem dos navios negreiros dos dois lados do Atlântico (Gilroy, 2003) - essa palavra adquiriu outros significados por meio de um processo definidor de matriz colonial que torna a genealogia do sincretismo semelhante à do fetichismo. Uma palavra especificamente grega - que não poderia ser mais grega - muda de sinal na travessia: ela afirmava a incapacidade helênica (não apenas cretense) de fazer alianças estáveis contra invasões inimigas e por uma política confederada entre cidades-estados. A autonomia cultural-política e linguística na Grécia clássica era o símbolo de sua história brilhante e irrepetível. E talvez até o limite... Os gregos certamente não eram superficiais, muito pelo contrário, segundo uma tradução enganosa de sincretismo. Filosofia, astronomia, história, tragédia, poesia, arte foram levadas aos níveis mais elevados e muitos (não apenas na Europa) são devedores da criatividade helênica. Nem mesmo o helenismo merece o rótulo de ecletismo que ressoa com remodelações pejorativas, nas quais o sincretismo também muda de significado enquanto se aguardam novas mutações em contextos pan-americanos...

Tal como acontece com o fetichismo, o conceito de sincretismo deve ultrapassar uma série de estigmas regressivos que foram estratificados em sua proposição, a serem identificados e possivelmente modificados por meio da análise histórico-antropológica. Nesse sentido, aqui se propõe um sentido diferente de sincretismo, que também herda os mais diversos sentidos que, de tempos em tempos, se misturaram. O mais atual é o significado do sincretismo religioso, a que é muito difícil se opor.

Essa pesquisa combina o sincretismo com o conceito de cultura nos diferentes significados da antropologia contemporânea: valores, modelos de comportamento, estilos de vida, visões de mundo. Os sincretismos atuais constituem uma 
palavra-chave para entender a transformação da relação entre culturas e política nos processos de globalização e localização que envolvem e desorganizam as formas tradicionais de produção de identidade em relação ao outro diferente de si. Os sincretismos culturais abrem as fronteiras para entender um contexto feito de aceleradas e confusas mutações; eles podem direcionar essa crescente desordem comunicativa em direção a correntes criativas, descentralizadas e abertas. $\mathrm{O}$ sincretismo incorpora o paradoxo de uma palavra muito instável, dos excessos polissêmicos às suas excessivas mutações de sentido. Muitas vezes se disfarça com sinônimos mais elegantes ou mais conflitantes, como pastiche, patchwork, cimaronismo, híbrido, mélange, mulatismo, pidgin, aculturação: todos ligados ao jogo ambíguo da contaminação transcultural. Nele coexistem os traços da incoerência, paixão, trivialidade, indigenização que estão estilhaçando o poder adquirido pelo trio estética-ética-etnicidade. Nos comportamentos cotidianos, o sincretismo investe, dissolve e remodela a relação entre o estrangeiro e o familiar, entre as culturas de elite e de massa, entre os estilos da vanguarda e os digitais. O sincretismo não é um "lugar comum": é um espaço misto e mutante, que cria estupor, raiva e conflito.

O sincretismo inclui o cenário em que a "clareza sombria" das oposições binárias retrocede a um passado que retorna ao presente graças a simplificações extremas, funcionais ao ódio e ao ressentimento. O sincretismo aceita o desafio desse cenário não comum, navega pela angústia difusa da invasão extraeuropeia e da homologação global, elabora modelos alternativos, acentuando as propostas transculturais. O sincretismo é avesso ao conceito "nobre" de síntese, oferece coexistências conceituais diversificadas em vez de estar sujeito ao encanto unificado de uma lógica eurocêntrica. Dicotomias, homologações, sínteses são cenários lógicos e políticos clássicos que os sincretismos atuais enfrentam ao navegar lateralmente em direção a outras correntes.

Depois do uso filosófico depreciativo, a etnografia assume a experimentação inquieta do sincretismo, aceita sua mudança na direção de trânsitos xenófilos e de fragmentos incompatíveis. O sincretismo emerge das pesquisas no campo transcultural e está se remodelando na comunicação digital, apesar da dificuldade de ser "normatizado". Os cenários compostos por uma mistura de códigos estranhos pertencem às experiências cotidianas: eles podem recombinar diferenças étnico-culturais, exercitando a riqueza de seu agenciamento desordenado. Um projeto etnográfico aplicado aos sincretismos está pronto para se lançar nos mais diversos aspectos da comunicação analógica e digital, ao lado de outras palavras constelares.

Na década de 1980, o movimento cyberpunk de William Gibson - influenciado por Marshall McLuhan - desenvolveu rastros sincréticos entre os códigos vodu e o ciberespaço. Com o Neuromancer (Gibson, 1984), a palavra cyberpunk 
já está presente, unindo a contracultura punk com as inovações cyber. Também do Canadá, David Cronenberg escreveu seu primeiro romance, Consumed (Cronenberg, 2014), fazendo conexões entre os corpos mutantes de seus filmes com uma antropofagia digital atravessada pela out-of-body existence e por uma estética cancerígena:

Muitas mulheres têm câncer agora. Você acha que uma nova estética pode se desenvolver? Beleza do câncer? Quer dizer, como se fosse a heroína chique, a estética do viciado em drogas que anseia pela morte? Será que as mulheres não cancerosas vão implorar ao cirurgião plástico para aplicar nódulos falsos sob o queixo e ao redor do pescoço? Sob seus braços? Em suas virilhas? Tão sexy, aquela plenitude. E funciona tão bem como uma técnica anti-envelhecimento, para encher aquela papada de peru flácido. Quem não gostaria? E as joias, as bolas de titânio que perfuram aqueles seios. (Cronenberg, 2014, p. 53)

A antropofagia foi um movimento de vanguarda no contexto paulista do Brasil (Andrade, 1924/1999). Agora, um novo gênero literário se apresenta: cyberphagy - uma ciber-antropofagia - por meio da qual Cronenberg libera sua compulsão de ter seu amante ou a si mesmo devorado. $\mathrm{O}$ entrelaçamento entre sincretismo e fetichismo - ligado ao colonialismo não resolvido - é minha hipótese básica que evoco aqui graças a Cronenberg, um mestre do fetichismo com Videodrome (Cronenberg, 1983). Em seu romance, ele imagina a obra de arte consumed, que é consumida, devorada, antropofagizada. E a beleza de uma carne cancerígena é expressa graças às células de pixel, a serem exibidas no necrotério transfigurado em uma galeria de arte para a ressurreição digital:

Ele poderia, de fato, dizer algo sobre os conceitos clássicos da arte e, portanto, sobre a beleza, baseada na harmonia, em contraste com as teorias modernas, a revolução pós-industrial, a pós-psicanálise baseada na doença e na disfunção? Ele poderia apresentar um caso para seu novo eu doentio como a forma mais vanguardista da beleza feminina? Ele não ousou, mas ela sim. (Cronenberg, 2014, p. 57)

A disfunção do corpo e a desordem da artista criam uma obra que oscila entre o body-corpse, que flui na linha que une e separa o corpo-vivo e o corpo-morto. Finalmente, em Cronenberg, a estética "sincretiza" o duplo significado de beauty-centre e filosofia autoconsciente graças a cirurgias estéticas, doenças terminais e tecnocorpos manipulados. Quando uma pessoa morre, sua identidade, sua história e seus afetos continuam a ser devorados (consumed) pelos seguidores das redes sociais. A linha divisória entre a vida e a morte torna-se 
tênue - o próprio traço do body-corpse torna-se quase invisível. O sucesso global das séries televisivas em hospitais cirúrgicos e enfermarias mortuárias deve ser seriamente analisado como uma mudança de uma estética "popular" ilimitada que quer consumir o horror transfigurado em uma obra de arte. $\mathrm{O}$ cadáver volta a ser a matéria-prima de uma obra artística privada da sacralidade arcaica, mas transcendente, graças à out-of-body existence. O cirurgião da autópsia idealiza o destino da humanidade e o torna público: cada espectador quer ver com os próprios olhos - aủtó č ó cadáveres. Imagino que as belas artes graduem um número cada vez maior de alunos com especialização na arte cadavérica ou obituário museal, cujos produtos sejam solicitados por seriados de autópsia. O verdadeiro herói discreto e simpático dos seriados é ele: o dissecador de corpos que sempre descobre o assassino e não o assassinado.

A autópsia digital é sincrética e extremamente fetichista. É democrático porque todos têm o direito de ver com os próprios olhos. É seriada porque nunca termina.

O sucesso dessas perspectivas sincréticas se deve à irrupção de alguns temas antropológicos nos movimentos contemporâneos, graças às mudanças ocorridas na cultura cotidiana. Essa última não é mais vista como algo unitário, que compacta e une indivíduos, sexos, grupos, classes, etnias: antes, é muito mais plural, descentralizada, fragmentada, conflituosa e relativa. Voltando ao chamado descobrimento (a "descoberta" das Américas), desde esse momento, o sincretismo tem sido quase exclusivamente associado a fenômenos religiosos, então, mesmo agora, os dois termos são frequentemente associados; entretanto, um processo que aplicou as modulações sincréticas às culturas urbanas e visuais (street art, public art, visual art, design expandido, moda, publicidade, literatura, um certo cinema e muita música) vem se consolidando há algum tempo. E justamente esses movimentos que flutuam nos sincretismos culturais são o tema desse discurso. Eles brotam, indisciplinados e incoerentes, das múltiplas dobras da contemporaneidade: para subvertê-la ou, pelo menos, surpreendê-la. Às vezes até para confundi-la, até mesmo simplificá-la ou amaldiçoá-la.

A própria origem da palavra - que possui qualquer coisa de enigmática e alusiva nas sucessões fonéticas - é quase um mito filológico. Dizia-se, de fato, que os cretenses, sempre dispostos a brigar entre si, aliaram-se como bons helenos quando apareceu um inimigo externo.

Sin-cretismo = união ou confederação dos cretenses.

Seria um conceito defensivo, portanto, bem como uma metáfora para o comportamento grego em geral, unir-se para tentar superar sua fragmentação política interna, a fim de não perder o valor da liberdade e derrotar um inimigo 
externo muito pior que o "amigo" competitivo interno. Esse desejo de unir grupos internos conflitantes, essa busca por alianças entre as diferentes "partes" da própria Creta, marcou as sucessivas migrações do conceito: da política à filosofia e às religiões. Assim, as tentativas sincréticas referem-se a combinações momentâneas entre diferentes religiões ou crenças, sem preocupação com as ortodoxias de estados e igrejas. E por isso os movimentos sincrético-religiosos e políticos sempre se expõem a heresias, perseguições, execuções, mas também tolerâncias interessadas.

Daí, a ambígua assonância do sincretismo com a "superficialidade", que desde há muito marcou o seu sentido por parte das "profundidades" filosófico-religiosas. E assim seu uso constante, no início da era moderna, para indicar um dos maiores etnocídios cometidos pela cultura ocidental. Após a "conquista" das Américas, de fato, os conquistadores constataram que os chamados selvagens (os "nativos") não podiam trabalhar em condições de escravidão. Como resultado, eles foram mortos ou foram deixados para morrer, eles até mesmo se recusaram a ter filhos que nascessem em um mundo tão feroz. Surgiu então a ideia de importar uma força de trabalho mais adaptável a esse tipo de trabalho e teve início a diáspora africana. Pessoas escravizadas foram transportadas em condições desumanas de outro continente, porque a mão de obra indígena era inutilizável ou quase eliminada. Por isso, algumas das formas mais criativas de sincretismo surgem da diáspora africana nas Américas, apesar (ou por causa) do imenso sofrimento.

Porém, para os valores católicos e mesmo humanísticos dominantes na época, não bastava transformar o corpo de um ser humano em escravo. Devia-se converter também a alma ou espírito. A pessoa reduzida a escravo deveria aceitar as normatividades morais e os universais éticos de uma religião que não a sua, a qual foi rebaixada ao nível do animismo, superstição, magia; enquanto a outra, a vencedora, assumiu a luz espiritual da redenção ecumênica e da tecnologia no poder. O símbolo racional e perfeito - moral em sentido estrito, visto que se baseia na introjeção dos costumes (mores) - da escravidão foi e continua sendo a focinheira humana ou mordaça de ferro. A ferramenta, que, para um animal domesticado (cavalo), ainda é chamada de "morso", foi usada em seres humanos para domesticar a rebelião contra a condição de escravatura. Não apenas para os escravos: os hereges também sofreram a mesma punição ao serem privados do direito de falar.

A tortura inimaginável de ter um pedaço de ferro entre os dentes que o impede de falar, beber e que só se pode morder em todo o tempo que se trabalha nas plantações, foi narrada pela escritora afro-americana Toni Morrison. Em seu romance Amada (Morrison, 2009), ela recria o que uma pessoa com 
uma mordaça de ferro entre os dentes deve ter sentido por 12-15 horas por dia. Uma loucura contida e violada pelos capilares dos olhos que avermelhavam o olhar, pela lenta baba que se coagulava nos lábios, pela respiração difícil, por uma raiva explosiva e desviada. Morder a mordaça é a história tecnológica do Ocidente exportada cientificamente para as Américas.

Essa tecnologia moral unia tortura e trabalho para empurrar os oprimidos a buscar uma solução para sua condição: algumas delas eram o cimarrón, o quilombo e o sincretismo. Nesse último caso, uma espécie de pacificação implícita entre vencedores e perdedores foi estabelecida nas práticas religiosas das Américas. Os oprimidos aceitaram que haviam se convertido para inserir divindades, tradições, rituais dentro dos vitoriosos, em um pacto implícito de sobrevivência e produtividade mútuas. Em troca, os governantes reconheceram extraoficialmente fragmentos das religiões de origem em aspectos marginais do cristianismo: uma clássica condescendência católica contra uma rigidez ortodoxa protestante. Portanto, o sincretismo religioso apresentava-se mais uma vez sob o signo do compromisso defensivo: a aliança invasiva da religião dominante era aceita, desde que permitisse certa tolerância aos cantos, danças e divindades.

E então Iemanjá se disfarça de Madonna com seios túrgidos e quadris generosos. A deusa da água e do amor que realizou a travessia do Atlântico é vestida de azul, para continuar a ser a mãe de todos os Orixás - as divindades iorubás. E os gêmeos lbêji se duplicaram nos santos Cosme e Damião, enquanto Exu impropriamente se torna o diabo pelo clássico "vício" eurocêntrico de ver arquétipos em todos os lugares. Jorge Amado (1987), o grande escritor baiano, diz que Exu é

um orixá entre os mais importantes da liturgia do candomblé, orixá do movimento, confundido por muitos com o diabo no sincretismo com a religião católica, porque é malicioso e impertinente, não consegue ficar quieto, adora confusão. Exu come tudo o que cai na boca, bebe cachaça, é cavaleiro andante e menino reinador. Ama a folia, senhor dos caminhos, mensageiro dos deuses, carteiro dos orixás, um inquieto. Por tudo isso, o sincretizaram com o demônio: na realidade ele é somente um orixá em movimento, amigo de um bafafá, da confusão, mas, basicamente, uma ótima pessoa. Em certo sentido é o Não onde só existe o Sim, o Contra em meio ao a Favor: intrépido e invencível. (p. 20)

Essa defesa de Exu de sua identificação indevida (isto é, "sincrética") com o demônio católico é extraordinária não apenas pelo estilo poético de Amado, mas porque a citação destaca uma perspectiva totalmente diferente. Exu - como menino reinador sob a bandeira do "Não" - liberta a religião afro-brasileira do 
candomblé de ter que se disfarçar, para sobreviver, dentro da religião católica; liberta os orixás de serem uma tradução africana de divindades greco-romanas ou santos católicos, devido às influências junguianas reproduzidas por Pierre Verger, grande fotógrafo e mau etnólogo. O resultado é a libertação do sincretismo da confusão religiosa do passado para abrir os caminhos da cultura cotidiana. Uma experiência etnográfica inicial minha foi fundamental: alguns amigos afro-brasileiros do Rio de Janeiro me convidaram para participar de alguns rituais de candomblé em um pequeno terreiro a algumas horas da cidade. O terreiro é o lugar sagrado onde se realizam os rituais e onde vive a Mãe de Santo, autoridade religiosa máxima que (ao contrário das religiões monoteístas) é descentralizada. Na segunda vez que lá estive, eles me apresentaram a ela, a Meninazinha, nome muito usado pela Mãe de Santo. Conversamos muito, ou melhor, ouvi suas visões com grande interesse: ela era uma mulher forte, austera e autoritária, de cerca de 60 anos, com muitos colares e um turbante magnífico. Os olhos emitiram lampejos de clareza que não permitiram discussão. Uma grande mulher. A certa altura, ousei fazer uma pergunta que "já" havia imaginado sobre sincretismo e candomblé. Seus olhos brilharam mais do que o normal e ela me explicou que sua religião há muito rejeita o sincretismo, que tem plena autonomia cosmológica, ritual e sagrada, sem interferências externas. Era o passado e agora também o catolicismo, disse, reconhece a dignidade autônoma do candomblé.

Uma verdadeira lição de história das religiões.

A recente autonomia do candomblé em relação ao catolicismo possibilita o uso do sincretismo em um sentido comunicacional, estético e cultural, deslocando-o para além da história cretense ou da colonial. Esse sincretismo libertado seduz quem aceita o risco de mudar e viajar, ao deslocar-se nos muitos "alhures" e assim juntar-se ao "senhor dos caminhos", o eu infantil e lúdico do menino reinador. Os sincretismos culturais afirmam os códigos da alteridade inquieta, dos pensamentos impertinentes, da divagação imprevisível, do desejado espanto. O sincretismo é um orixá laico em movimento e de movimento: contra os imobilismos psíquicos, as reproduções padronizadas, as retrocessões cíclicas das paradas arquetípicas.

O sincretismo cultural é assim precisamente porque nega toda tensão e dignidade à ordem sintética, à superação dialética, ao evolucionismo unilinear. Dentro de seu conceito reside uma sensação de desordem, de confusão, de irregularidade: de um movimento de desejo e de uma perambulação inquieta. $\mathrm{O}$ sincretismo cultural nasceu com o surgimento dos quilombos no Brasil: espaços libertados daqueles que recusaram a condição de escravidão e se armaram contra o senhor de escravos. O ato simbólico do quilombo era a fuga, a "grande fuga". A não aceitação de uma ordem cultural imponente e destrutiva. É aqui que 
nasce a palavra "cimaronizar", na qual - como se verá - não há vestígios de cor escura: cimaronizar não significa diluir o preto em branco ou, pelo contrário, escurecer o branco. $\mathrm{O}$ cimaronismo foi uma escolha política para fundar, ao fugir, um "espaço autogovernado de liberdade". Um quilombo, precisamente. E a liberdade desse quilombo não era apenas religiosa, mas cultural em sentido mais amplo. Essa liberdade não se restringia aos afro-americanos, mas a todos os seres humanos que viam na fuga o ato de libertar-se. Ladrões, prostitutas, indígenas, vagabundos, mestiços: todos eram acolhidos no espaço livre do quilombo.

\section{FETICHES}

Phantasós tem uma especialidade [ars] ainda diferente: se transforma em perfeição na terra, na rocha, no ar, no tronco, enfim, em qualquer coisa inanimada [quaeque vacant anima]. (Ovidio, 8/2015, livro XI, vv 642-3)

Aqui se apresenta uma genealogia antropológica do fetichismo por meio das fisionomias de corpos-mercadorias-coisas, para verificar se é possível praticar um meta-fetichismo para além dos estigmas psicoculturais incorporados pelo fetiche no decorrer das várias estratificações históricas. Nessa perspectiva, o meta-fetichismo favorece um reagir ("re-enacting") desejoso e mutável de ser envolvido com seu aliado mais fiel: a meta-morfose. A questão político-comunicacional do fetichismo é crescente, em particular devido à sua interconexão com a cultura digital, a partir da qual proliferam os mais diferenciados fetiches visuais. A partir desse contexto, configuro um cenário que transfigura esse conceito. A pesquisa trata do colonialismo português de que nasceu o feitiço, da legitimação de De Brosses (1760/2000) no Iluminismo, do desenvolvimento de Marx (1967) sobre a reificação, da aplicação de Freud (1981) nas perversões, até o uso trivial de "senso comum".

Tudo isso parece radicalmente inadequado.

Os fetiches visuais oferecem uma pragmática potencial além do dualismo clássico e da própria dialética, a fim de se libertar das incrustações estratificadas em seu corpo-coisa. Embora mesclado com a dominação, o fetichismo expressa um desejo perturbado, desviado e difuso nas mais diversas culturas. Os fetiches visuais transfiguram as relações entre olho/tela, corpo/mercadoria, carne/tecnologia, pele/pixel - talvez até vida/morte - por meio de manifestações míticas, sagradas, performáticas ou, em um sentido mais amplo, antropológicas que animam o que parece estar morto. O fetichismo conecta, cruza e vivifica reificações e petrificações, história e mito, tempos e espaços. Material e imaterial. 
Os fetiches visuais são transmitidos por atratores disseminados pela comunicação analógico-digital. Conectam panoramas corporais e interstícios metropolitanos; atraem as práticas de artistas, músicos, estilistas, diretores, escritores, designers e até arquitetos que lançam obras fetichistas. Sem fetiches não haveria as artes em sentido ampliado no público/privado.

A ubiquidade fetichista está dentro do corpo do capitalismo pós-industrial e nos corpos mitológicos arcaicos. Ambos os corpos são contemporâneos, no sentido de que coexistem, transbordam e se aceleram no cotidiano transcultural. A onipresença fetichista desafia o passado, o presente e o futuro - por isso é atual. Esse fetichismo não anima somente as mercadorias nem reifica contextualmente os

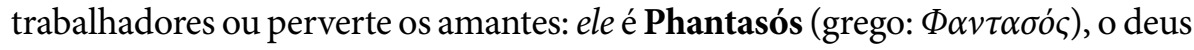
que vivifica o que é fixo, um objeto, uma coisa, uma imagem. Uma identidade. Por isso, os fetiches sincréticos envolvem o devir fisionômico das facticidades (latim Facticius), conceito sensorial sobre o qual viajam coisas, objetos, bens, pixels.

$\mathrm{O}$ fetichismo em geral - e em particular o espectro dos fetiches sincréticos - expressa uma tendência para além dos paradigmas dualistas. Por esta razão, ele vai além - esse é o meta-fetichismo - e se relaciona com o conceito semelhante (mas não idêntico) de meta-morfose, fonte de desejos contínuos expressos de forma diferente em tantas culturas. A minha hipótese é clara: os potenciais cruzamentos entre meta-fetichismos e meta-morfoses são exercidos por meio da expansão dos sincretismos culturais, incorporados à fisionomia das coisas, veiculados por atratores semióticos, atravessados pelo estupor metodológico. Esta mistura compulsiva de códigos, estilos, artes, música, modas desenha cenários ambíguos entre as culturas e a política contemporâneas: e talvez também anuncie um meta-fetichismo auroral - onipresente, polifônico, diaspórico e sincrético.

O conceito de matriz colonial - feitiço - esconde um desejo sombrio/luminoso que os portugueses procuraram encerrar em uma definição regressiva e subordinada, primitivista e animista, sem história e sem teologia. $\mathrm{O}$ animismo é a estrutura racional-eurocêntrica do fetichismo. O animismo como alma (anima) secundária e inferior, alma degenerada e subdesenvolvida, infantil e imatura, supersticiosa e mágica. Seu conceito é plenamente afirmado na época do Iluminismo, que - não só neste aspecto - permanece subordinado ao colonialismo, exceto por algumas figuras (Vico, Montaigne). Finalmente, fetichismo e animismo serão conjugados pela antropologia evolucionista em perfeita sincronia com a Revolução Industrial, o imperialismo político, as terminologias positivistas. Assim, o animismo foi projetado nas culturas primitivas do passado e do presente, cujo estigma eurocêntrico continua no uso diário e até acadêmico; entretanto, uma revisão do fetichismo, ao qual o animismo está imanentemente conectado, nunca começou. 
Essa operação sutil que justifica (parcialmente) o animismo e legitima (totalmente) o fetichismo desmascara a irracionalidade racional do pensamento humanista ainda dominante.

As potencialidades internas do fetichismo aspiram a estabelecer relações não antropocêntricas entre o que está morto e o que está vivo, entre o sagrado e o cotidiano, o sexo e a ótica, o trabalho e a arte. $\mathrm{O}$ fetichismo incorpora o desejo de perceber e vivificar fragmentos culturais para além do dualismo conceitual, paradigmas dicotômicos ou a dialética sintética: é uma filosofia pragmática e perturbadora, que sente as relações entre reificação e petrificação, entre mito e razão, entre estranho e familiar: e as resolve ou as dissolve. $\mathrm{O}$ fetichismo superior - ou meta-fetichismo - é a chave para afirmar uma antropologia não antropocêntrica na qual o humano já não é o centro das cosmologias; na qual se pode afirmar um policentrismo de entidades diversificadas que pode delinear outras imaginações cosmológicas; na qual é possível sentir a pacificação entre seres humanos, animais, plantas, minerais - e até divinos.

Chamo de meta-fetichismo esta constelação - ubíqua, sincrética, polifônica, diaspórica - atraída por meta-morfoses, onde flutuam desejos utópicos e esperanças ubíquas, performances marginais e obras sublimes. A imaginação precisa do meta-fetichismo explora visões em direção a uma antropologia não antropocêntrica: onde coisas, mercadorias, objetos (as "facticidades") são libertados da sentença de serem apenas úteis ou inertes, para serem transfigurados em corpos, peles, olhos, rostos, perfumes, zíperes, sombras, máscaras, múmias, bonecos, autômatos, interstícios, edifícios, música, poesia. Os meta-fetiches cruzados com meta-morfoses afirmam o potencial de subverter o "estado das coisas": porque as coisas são materiais/imateriais e não têm estado, mas movimento, são seres transitivos além do humanismo.

Estendo ao fetichismo o método de Edward Said no que diz respeito do orientalismo. Não é apenas o "Oriente" que se narra segundo reducionismos interpretativos, estereótipos generalizantes, racismos degenerativos por parte das principais instituições culturais europeias, in primis França e Grã-Bretanha, ainda que nenhuma nação seja excluída. Se "o Oriente foi orientalizado" (Said, 1979/2003, p. 8), também o fetichismo foi fetichizado. Não só o orientalismo, portanto, mas também o fetichismo sofreu um preconceito semelhante por parte das principais agências de conhecimento primeiramente europeias e agora globais. Em um estranho paradoxo, o fetichismo é um conceito central da dominação ocidental que, usado para estigmatizar o "outro", penetra no próprio corpo-mente do próprio Ocidente e depois se expande globalmente. O fetichismo é ubíquo no sentido radical, porque unifica e mistura diferentes tempos/espaços, e porque mostra que o enigma da dominação - que muitas 
vezes também se reproduz por meio dos dominados - ainda espera para ser desvendado em sua racionalidade mitológica intacta. O fetichismo é o enigma do Ocidente que não deve ser revelado ou talvez possa ser resolvido, liberando os sonhos de Phantasós. M

\section{REFERÊNCIAS}

Adorno, T. W. (1937). Spätstil Beethovens. Der Auftakt, 17(5-6), 65-67.

Adorno, T. W. (1955). Minima moralia. Einaudi.

Adorno, T. W. (1966). Dialettica negativa. Einaudi.

Amado J. (1987). Due storie del porto di Bahia. Garzanti

Andrade, O. (1999). Manifesto antropofagico. Meltemi (Obra original publicada em 1924)

Bakhtin, M. (1988). L'autore e l'eroe. Einaudi.

Bateson, G. (1976). Verso un'ecologia della mente. Adelphi.

Bateson, G. (1988). Naven. Einaudi.

Barenboim, D. (2007). Everything is connected: The power of the music. Verso.

Barenboim, D., \& Said, E. (2004). Parelleli e paradossi: Pensieri sulla musica, la politica e la società. il Saggiatore.

Bernhard, T. (1985). Il soccombente. Adelphi.

Berners-Lee, T. (2017, 12 de março). Tim Berners-Lee: I invented the web. Here are three things we need to change to save it. The Guardian. https:// bit.ly/3dQPOpp

Boccioni, U. (1910-1911). La città che sale [Pintura]. Museum of Modern Art, Nova Iorque, Estados Unidos.

Canevacci, M. (2015, 20-24 de abril). Ubiquitimes: The ethnographic experiences of digital cultures and the syncretic mix of spacetimes [Artigo apresentado]. Seminário sobre "Tempo", Instituto de Estudos Avançados, Universidade de São Paulo, São Paulo, SP, Brasil. https://bit.ly/3txW8sN

Canevacci, M. (2018). La linea di polvere. La cultura Bororo tra tradizione, mutazione e auto-rappresentazione. Meltemi.

Cronenberg, D. (Diretor). (1983). Videodrome [Videodrome: A síndrome do vídeo] [Filme]. Canadian Film Development Corporation.

Cronenberg, D. (2014). Consumed. Forth Estate.

De Brosses, C. (2000). Du culte des dieux fétiches ou Parallèle de l'ancienne religion de l'Égypte avec la religion actuelle de Nigritie. Fayard. (Obra original publicada em 1760)

Documenta X. (1997). Politics: Poetics [Catálogo]. Cantz.

Durham, J. (1993). A certain lack of coherence. Kala Press. 
Freud, S. (1977). Il perturbante. In Opere di Sigmund Freud (vol. 9, pp. 81-114). Bollati Boringhieri.

Freud, S. (1981). Feticismo. In Opere di Sigmund Freud (vol. 10, pp. 487-497). Bollati Boringhieri.

Gibson, W. (1984). Neuromancer. Victor Gollancz.

Gilroy, P. (2003). The black Atlantic. Meltemi.

Malara, A. (2020, 6 de março). Coronavirus, l'anestesista di Codogno che ha intuito la diagnosi di Mattia: "Ho pensato all'impossibile" [Entrevista a Giampaolo Visetti]. La Repubblica. https://bit.ly/2RNa7gi

Marcus, G. (1995). Ethnography in/of the world system: The emergence of multi-sited ethnography. Annual Review of Anthropology, 24, 95-117. https:// doi.org/10.1146/annurev.an.24.100195.000523

Marx, K. (1967). Il capitale. Editori Riuniti.

Morrison, T. (2009). Amatissima. Sperling \& Kupfer.

Ovidio. (2015). Le metamorfosi. Einaudi. (Obra original publicada em 8)

Rutgers University (2010, 5 de fevereiro). Computer science challenges for the next 10 years [Vídeo]. YouTube. (Obra original de 1996)

Said, E. (1999). Out of place. Granta.

Said, E. (2003). Orientalism. Pantheon. (Obra original publicada em 1979)

Said, E. (2006). On late style. Pantheon.

Artigo recebido em 4 de março de 2021 e aprovado em 7 de abril de 2021. 